\title{
PRODUCTIVITY OF INTERCROPPING MAIZE (Zea mays L.) AND PUMPKINS (Cucurbita maxima Duch.) UNDER CONVENTIONAL VS. CONSERVATION FARMING SYSTEM
}

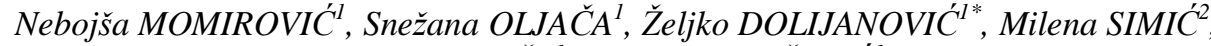 \\ Mićo OLJA $\check{C} A^{l}$, Biljana JANOŠEVIĆ ${ }^{l}$ \\ ${ }^{1}$ Belgrade University, Faculty of Agriculture, Nemanjina 6, Belgrade, SERBIA \\ ${ }^{2}$ Maize Research Institute, Slobodana Bajica 1, Belgrade, SERBIA \\ *Corresponding author: dolijan@agrif.bg.ac.rs
}

Received: 04.02.2014

\begin{abstract}
The evaluation of pumpkin (Cucurbita maxima Duch.) and maize (Zea mays L.) intercropping productivity, under different farming systems: conventional farming vs. conservation farming was carried out on the chernozem type of soil at Zemun Polje, Serbia. Results obtained by the bivariate analysis of variance showed significant differences between different proportions of components in intercropped maize and pumpkins. Regarding the land equivalent ratio (LER), two rows of pumpkins and two rows of maize (proportion 2/3:1/3) were the optimum spatial arrangement in conventional farming system, while proportion 1/3:2/3 was optimal in conservation farming system. The yield of pumpkins proportionally increased with the increase of the plant population, although the intraspecies competition of pumpkins was very pronounced in intercropping with maize. The average fruit yield of pumpkins in the first year was lower in conservation farming practices in comparison with conventional farming practices. On the other hand, situation was complete opposite with pumpkin yield in second year of investigation, while significant decrease in maize yield was observed in the plots where conservation farming practices were applied. Growing pumpkins in mixture with maize probably costs a small farmer very little more effort, than the production of a sole stand of maize. At least where the productivity of mixture is dominated by one species, as with maize in maize-pumpkins intercropping, the competitive effect of the recessive species on the dominant is small.
\end{abstract}

Key words: Conventional farming; Conservation farming; Intercropping; Maize; Pumpkin.

\section{INTRODUCTION}

The cropping system is very important for weed control, considering that weeds can cause great damages to crops and decreased yield (Videnović et al. 2013). Intercropping, as a cropping system, is defined as the intensification and diversification of cropping in time and space dimensions (Francis 1986). The intensification of land and resource uses in the space dimension is an important aspect of multiple cropping in efforts to develop energy-efficient and sustainable agriculture. The considerable variation in soil and climate has resulted in large variation in yield performance of maize hybrids annually (Ilker et al. 2009). Biological potentials of intercropping, such as enhanced efficiency of incident light use if two species, occupying the same land area (different pattern of foliage display, then different rooting patterns, etc.), can be realized when the interspecific competition is smaller than intraspecific competition in the same environment (Liebman and Staver 2001; Dolijanović et al. 2013). The final advantages of intercropping are a greater resource use and significant yield benefits (Francis 1986; Gliessman 1986; Oljača
1998; Dolijanović et al. 2007; Yang et al. 2010). Deficit irrigation, by reducing irrigation water use, can aid in coping with situations where water supply is restricted. (Kuscu et al. 2013). In some situations, farmers are interested primarily in obtaining full yield of one main crop, but sowing other species into the main crop for additional benefits: more food and fodder, improved soil conservation, and better weed control (Willey 1979a; Birkás et al. 2006). The additive intercropping design is based on these principles. However, the essence of the replacement series is to obtain optimum yields of both crops, which can be achieved only in case of the most favorable relations of crops in the mixture.

Relationships between components in intercropped maize (Zea mays L.) and pumpkins (Cucurbita maxima Duch.) were studied by numerous authors (Conteras Magana and del Castillo 1991; Powers et al. 1993; Galloway and Weston 1996; Silwana and Lucas 2002). Pumpkin, because of its ability to tolerate shade and cool temperatures, and to cover ground rapidly with its creeping growth habit, is often intercropped with maize. This intercropping system could be effective in 
suppressing weed growth and increasing crop yields and should be incorporated into the integrated weed management and Cropping System Design.

Intercropping systems have potential difficulties and limitations that prevent their application on large areas (Biabani et al. 2008; Mudita et al. 2008; Biabani 2009). There are many reasons for this: lack of machinery necessary for such purposes, difficulties for plant protection, lack of varieties and hybrids better-adapted to such growing conditions, small scale farming and lack of marketing possibilities etc. In Serbia, maize is being produced on 1.2 million hectares across the country (Mitrović et al. 2012), usually as a monocrop. The best cultivars for sole crop might not be the most suitable for mixed cropping.

In some regions, lately, where stressful conditions including drought and high temperatures occur frequently, broad environmental tolerance associated with mixed population of different crops may play a significant role in yield stability.

The aim of this study was to determine the relationship between maize and pumpkins, grown in the association under different farming practices and also to identify the most efficient and productive maize - pumpkins intercrop combinations. It is expected that maize and pumpkins will have higher yields in intercropping system due to their ability to use natural resources differently and make better overall use of natural resources than grown separately.

\section{MATERIALS AND METHODS}

The evaluation of pumpkin (Cucurbita maxima Duch. cv. Dill's Atlantic Giant) and maize (Zea mays L. cv. ZP SC 709d "double ear") intercropping productivity, under different farming systems, conventional farming vs. conservation farming, was carried out in the experimental field of the Maize Research Institute (MRI) in Zemun Polje near Belgrade $\left(44^{\circ} 52^{\prime} \mathrm{N} 20^{\circ} 20^{\prime} \mathrm{E}\right)$ during 2010 and 2011 on the chernozem type of soil. Randomized complete block design was applied with a four-replication. The maize crop was sown in $0.8 \mathrm{~m}$ plant spacing and 0.35 $\mathrm{m}$ row spacing (35714 plants $\left.\mathrm{ha}^{-1}\right)$ in pure stands. The corresponding values for pumpkins were $1.6 \mathrm{~m}$ and $2 \mathrm{~m}$ (3125 plants $\mathrm{ha}^{-1}$. There were three combinations in mixtures following the method of replacement series (de Wit 1960): 2/3 pumpkins: $1 / 3$ maize - where two rows of pumpkins replaced two rows of maize; $1 / 2$ pumpkins: $1 / 2$ maize - where a single row of pumpkins replaced two rows of maize; $1 / 3$ pumpkins: $2 / 3$ maize - where a single row of pumpkins followed by four rows of maize. Plant spacing in mixtures was the same as in the pure stands of both crops.

The previous crop was winter wheat. After stubble disking, deep ploughing to the depth of $35 \mathrm{~cm}$ was done in autumn. The common cropping practices were applied within the conventional farming system. Plots under conventional farming were fertilized with $120 \mathrm{~kg} \mathrm{~N}$ $\mathrm{ha}^{-1}, 100 \mathrm{~kg} \mathrm{P}_{2} \mathrm{O}_{5} \mathrm{ha}^{-1}$ and $80 \mathrm{~kg} \mathrm{~K}_{2} \mathrm{O} \mathrm{ha}{ }^{-1}$ in form of combined NPK fertilizer. The total amount of $\mathrm{P}_{2} \mathrm{O}_{5}$ and $\mathrm{K}_{2} \mathrm{O}$ and $50 \%$ of $\mathrm{N}$ fertilizers were applied in autumn and the rest of $\mathrm{N}$ fertilizers in spring, prior to sowing.

The pre-emergence application of Prometryne $(1.5 \mathrm{~kg}$ a.i. $\left.\mathrm{ha}^{-1}\right)$ and Pendimethalin $\left(1.320 \mathrm{~kg}\right.$ a.i. $\left.\mathrm{ha}^{-1}\right)$ was done. Winter vetch, as a cover crop, was sown in narrow rows after wheat stubble had been disked in plots in which conservation tillage was applied. When the cover crop was destroyed with Paraquat $0.8 \mathrm{~kg}$ a.i. ha ${ }^{-1}$ early in spring, decomposed wheat straw was applied in the amount of $5 \mathrm{t}$ ha $^{-1}$ to cover more than $60 \%$ of soil surface just before sowing of maize and pumpkins. Maize was sown in both years in the second decade of April, while four-week-old pumpkin transplants were planted on the beginning of May. Grain and fruit yields and other traits were recorded from each plot.

For the purpose of analyses, two broad approaches were used: the bivariate analysis of variance (Pearce and Gilliver 1978; Mead 1986) and Land Equivalent Ratio (LER) (Willey 1979b). Land equivalent ratio (LER) was calculated and used to evaluate the advantages in yields from intercropping: $L E R=\frac{Y_{1, \mathrm{z}}}{Y_{1,1}}+\frac{Y_{\mathrm{z}, 1}}{Y_{\mathrm{z}, \mathrm{z}}}$

where $Y_{1.1}$ and $Y_{2.2}$ are the crop yield for maize and pumpkin grown in monoculture, and $\mathrm{Y}_{1.2}$ and $\mathrm{Y}_{2.1}$ are yield of investigation crops in the mixture.

Results achieved were developed statistically with the analysis of variance (ANOVA) method. Yields per unit area of one component were plotted against that of another component as bivariate diagrams (Snaydon and Satorre 1989).

\section{RESULTS AND DISCUSSION}

In the experimental location, a total precipitation amounted to $466.5 \mathrm{~mm}$ and $486.0 \mathrm{~mm}$, during the growing season (April-September) of 2010 and 2011, respectively, while a 30-year average amounted to $410.8 \mathrm{~mm}$ (Figure 1). The precipitation distribution significantly differed over year, hence in June and September of 2010, the precipitation amounted to $107.1 \mathrm{~mm}$ and $128.8 \mathrm{~mm}$, respectively, that was two-fold higher than the long-term average. On the other hand, in 2011, August was characterized with high precipitation $(145.0 \mathrm{~mm})$. Temperature conditions were similar in both years of investigation (12.8 and $12.1{ }^{\circ} \mathrm{C}$ ) and also in accordance with the long-term average $\left(12.2^{\circ} \mathrm{C}\right)$. With regard to climatic requirements of these crops, it appeared that conditions were normal for the growth and development in both years 2010 and 2011 . 


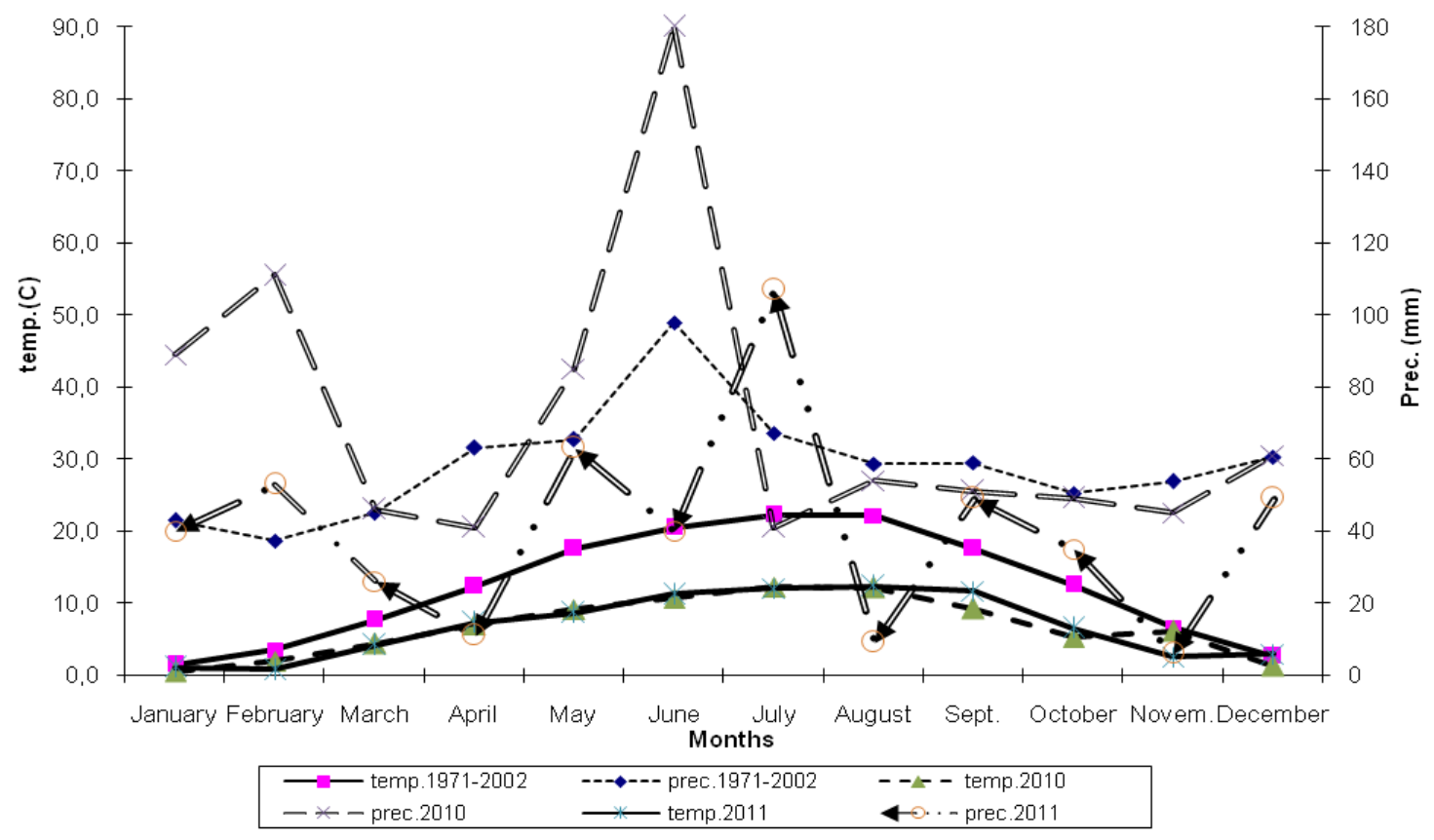

Figure 1. Meteorological data for long term (1971-2002) and experimental period (2010-2011)

Yields obtained in the sole crops of pumpkins were significantly higher than yields achieved in intercropping with maize, especially in the conservation farming system. The reduction of maize and pumpkin yields in different variants of intercropping in relation to sole crops was also established in previous studies (Silwana and Lucas 2002). Similar regularities were shown in the number and mass of pumpkin fruits per plants. Differences between treatments in number of pumpkin fruits per plants were not statistically significant (Table 1). The greatest number and mass of pumpkin fruits were obtained in the 2/3:1/3 variant in both farming systems, while the lowest values were gained in the 1/2:1/2 variant in the conventional farming system. It is interesting to emphasize that the average number of fruits per plants was lower in the sole pumpkin crops, but the fruit mass were greater than those in intercrops (Tables 1 and 2). The lowest ear number and the smallest grain mass per plant in maize were obtained in a sole maize crop, which is a logical consequence of the intensive intraspecies competition (Tables 3 and 4). Such regularity was particularly evident in the conservation farming system. Due to favorable meteorological conditions in the first year, the number of ears and grain mass per plant in maize were significantly greater in this farming system than in the second year of investigation, both in intercrops and sole crops. However, in respect to the conventional farming system, such trend was observed in the ear number but not in the grain mass per plant.

Table 1. Fruit number per plant of pumpkin in maize-pumpkin intercrop in different farming systems

\begin{tabular}{lcccccc}
\hline Intercropping & \multicolumn{3}{c}{ Conventional farming system } & \multicolumn{3}{c}{ Conservation farming system } \\
\cline { 2 - 7 } variants & $\mathbf{2 0 1 0}$ & $\mathbf{2 0 1 1}$ & Mean & $\mathbf{2 0 1 0}$ & $\mathbf{2 0 1 1}$ & Mean \\
\hline $1 / 3 \mathrm{p}: 2 / 3 \mathrm{~m}$ & 4.0 & 4.3 & 4.2 & 4.5 & 4.5 & 4.5 \\
$1 / 2 \mathrm{p}: 1 / 2 \mathrm{~m}$ & 4.3 & 3.8 & 4.0 & 4.5 & 5.0 & 4.8 \\
$2 / 3 \mathrm{p}: 1 / 3 \mathrm{~m}$ & 5.3 & 4.5 & 4.9 & 4.8 & 4.5 & 4.6 \\
Mean. & 4.5 & 4.2 & - & 4.6 & 4.7 & - \\
Sole crop & 4.8 & 4.5 & 4.6 & 4.5 & 4.5 & 4.5 \\
\hline \multicolumn{1}{c}{ S.E. (D.F.=24) } & 0.20 & 0.13 & - & 0.04 & 0.09 & - \\
\hline
\end{tabular}

p-pumpkin; m-maize; SE-standard error

Table 2. Fruit mass $(\mathrm{kg})$ of pumpkin in maize-pumpkin intercrop in different farming systems

\begin{tabular}{lcccccc}
\hline Intercropping & \multicolumn{3}{c}{ Conventional farming system } & \multicolumn{3}{c}{ Conservation farming system } \\
\cline { 2 - 7 } Variants & $\mathbf{2 0 1 0}$ & $\mathbf{2 0 1 1}$ & Mean & $\mathbf{2 0 1 0}$ & $\mathbf{2 0 1 1}$ & Mean \\
\hline $1 / 3 \mathrm{p}: 2 / 3 \mathrm{~m}$ & 18.2 & 11.8 & 15.0 & 15.0 & 13.1 & 14.0 \\
$1 / 2 \mathrm{p}: 1 / 2 \mathrm{~m}$ & 16.3 & 9.4 & 12.8 & 15.6 & 14.1 & 14.8 \\
$2 / 3 \mathrm{p}: 1 / 3 \mathrm{~m}$ & 19.0 & 18.3 & 18.7 & 18.3 & 16.3 & 17.3 \\
Mean. & 17.8 & 13.2 & - & 16.3 & 14.5 & - \\
Sole crop & 26.3 & 25.2 & 25.7 & 28.2 & 25.6 & 26.9 \\
\hline S.E. (D.F.=24) & 1.54 & 2.51 & - & 2.16 & 2.02 & - \\
\hline
\end{tabular}


Table 3. Ear number per maize plant in maize-pumpkin intercrop in different farming systems

\begin{tabular}{lcccccc}
\hline Intercropping & \multicolumn{2}{c}{ Conventional farming system } & \multicolumn{2}{c}{ Conservation farming system } \\
\cline { 2 - 7 } variants & $\mathbf{2 0 1 0}$ & $\mathbf{2 0 1 1}$ & Mean & $\mathbf{2 0 1 0}$ & $\mathbf{2 0 1 1}$ & Mean \\
\hline $1 / 3 \mathrm{p}: 2 / 3 \mathrm{~m}$ & 2.1 & 1.9 & 2.0 & 2.0 & 1.5 & 1.7 \\
$1 / 2 \mathrm{p}: 1 / 2 \mathrm{~m}$ & 2.2 & 1.9 & 2.0 & 2.1 & 1.7 & 1.9 \\
$2 / 3 \mathrm{p}: 1 / 3 \mathrm{~m}$ & 2.2 & 1.9 & 2.1 & 2.0 & 1.5 & 1.8 \\
Mean. & 2.1 & 1.9 & - & 2.0 & 1.6 & - \\
Sole crop & 2.0 & 1.8 & 1.9 & 1.9 & 0.3 & 1.6 \\
\hline S.E. (D.F.=24) & 0.04 & 0.03 & - & 0.04 & 06 & - \\
\hline
\end{tabular}

Table 4. Grain mass (g) per maize plant in maize-pumpkin intercrop in different farming systems

\begin{tabular}{lcccccc}
\hline Intercropping & \multicolumn{2}{c}{ Conventional farming system } & \multicolumn{3}{c}{ Conservation farming system } \\
\cline { 2 - 7 } variants & $\mathbf{2 0 1 0}$ & $\mathbf{2 0 1 1}$ & Mean & $\mathbf{2 0 1 0}$ & $\mathbf{2 0 1 1}$ & Mean \\
\hline $1 / 3 \mathrm{p}: 2 / 3 \mathrm{~m}$ & 467.9 & 480.8 & 474.3 & 475.5 & 411.2 & 443.3 \\
$1 / 2 \mathrm{p}: 1 / 2 \mathrm{~m}$ & 504.5 & 500.0 & 502.2 & 514.7 & 454.9 & 484.8 \\
$2 / 3 \mathrm{p}: 1 / 3 \mathrm{~m}$ & 525.5 & 541.1 & 533.3 & 493.8 & 411.2 & 452.5 \\
Mean. & 499.3 & 507.3 & - & 494.6 & 425.7 & - \\
Sole crop & 448.7 & 471.0 & 459.6 & 437.1 & 358.5 & 397.8 \\
\hline S.E. (D.F.=24) & 12.28 & 11.00 & - & 11.65 & 13.95 & - \\
\hline
\end{tabular}

p-pumpkin; m-maize; SE-standard error

The effects of all intercropping variants on maize grain yield were favorable in the conventional farming system. The maize grain yield was higher in the first combination in mixtures $1 / 3: 2 / 3$ pumpkins to maize, in both farming systems and in both years (Table 5). The lower participation of maize in the mixture was resulted in the lower maize grain yield in both farming systems. In second year, the highest $\left(8410.5 \mathrm{~kg} \mathrm{ha}^{-1}\right)$ and lowest yield $\left(6401.5 \mathrm{~kg} \mathrm{ha}^{-1}\right)$ of a sole crop of maize was obtained in the conventional and conservation farming system, respectively. According to results on pumpkin yields presented in Table 6 , it is notable that the conservation farming system had some advantages in relation to the conventional farming system. The only higher yield achieved in the conventional farming system was in the $2 / 3: 1 / 3$ intercropping variant in which pumpkins prevailed, hence the effect of a greater number of this species, in the interaction with reduced tillage, on the yield was adverse. In this way, the highest pumpkin yield in the conventional farming system was in the $2 / 3: 1 / 3$ intercropping variant, particularly in $2010(33649.5 \mathrm{~kg}$ ha $\left.{ }^{1}\right)$. The lowest pumpkin yields were obtained in the $1 / 3: 2 / 3$ variant, in both farming systems $(10535.3$ and $11032.4 \mathrm{~kg}$ $\mathrm{ha}^{-1}$ ), and yield proportionally increased with the increase of the plant population of pumpkins, although the intraspecies competition of pumpkins was very pronounced in intercropping with maize.

Table 5. Maize grain yield $\left(\mathrm{kg} \mathrm{ha}^{-1}\right)$ in maize-pumpkin intercrop in different farming systems

\begin{tabular}{lcccccc}
\hline Intercropping & \multicolumn{2}{c}{ Conventional farming system } & \multicolumn{2}{c}{ Conservation farming system } \\
\cline { 2 - 7 } Variants & $\mathbf{2 0 1 0}$ & $\mathbf{2 0 1 1}$ & Mean & $\mathbf{2 0 1 0}$ & $\mathbf{2 0 1 1}$ & Mean \\
\hline $1 / 3 \mathrm{p}: 2 / 3 \mathrm{~m}$ & 5567.8 & 5721.8 & 5644.8 & 5658.1 & 4893.0 & 5275.6 \\
$1 / 2 \mathrm{p}: 1 / 2 \mathrm{~m}$ & 4504.2 & 4464.3 & 4484.3 & 4595.9 & 4061.7 & 4328.8 \\
$2 / 3 \mathrm{p}: 1 / 3 \mathrm{~m}$ & 3127.3 & 3220.3 & 3173.8 & 2938.6 & 2447.1 & 2692.9 \\
Mean & 4399.8 & 4469.1 & - & 4397.5 & 3800.6 & - \\
Sole crop & 8011.9 & 8410.5 & 8211.2 & 7804.6 & 6401.5 & 7103.1 \\
\hline S.E. (D.F.=24) & 729.73 & 784.81 & & 720.66 & 583.34 & \\
\hline
\end{tabular}

p-pumpkin; m-maize; SE-standard error

Table 6. Pumpkin yield $\left(\mathrm{kg} \mathrm{ha}^{-1}\right)$ in maize-pumpkin intercrop in different farming systems

\begin{tabular}{lcccccc}
\hline Intercropping & \multicolumn{2}{c}{ Conventional farming system } & \multicolumn{2}{c}{ Conservation farming system } \\
\cline { 2 - 7 } variants & $\mathbf{2 0 1 0}$ & $\mathbf{2 0 1 1}$ & Mean & $\mathbf{2 0 1 0}$ & $\mathbf{2 0 1 1}$ & Mean \\
\hline $1 / 3 \mathrm{p}: 2 / 3 \mathrm{~m}$ & 12499.9 & 8570.6 & 10535.3 & 11783.5 & 10281.3 & 11032.4 \\
$1 / 2 \mathrm{p}: 1 / 2 \mathrm{~m}$ & 18104.7 & 9084.9 & 13594.8 & 18371.8 & 17772.6 & 18072.2 \\
$2 / 3 \mathrm{p}: 1 / 3 \mathrm{~m}$ & 33649.5 & 28858.5 & 31254.0 & 30108.3 & 25022.3 & 27565.3 \\
Mean. & 21418.0 & 15504.7 & - & 20087.9 & 17692.1 & - \\
Sole crop & 65871.9 & 57903.3 & 61887.6 & 66379.8 & 59934.5 & 63157.2 \\
\hline S.E. (D.F.=24) & 8471.14 & 8205.35 & & 8610.91 & 7764.73 & \\
\hline p-pumpkin; $\mathrm{m}$-maize; SE-standard error & & & & &
\end{tabular}


From the biological aspect, the explanation of the advantages of intercrops over sole crops is similar to the explanation of the survival of the species in the natural communities (Dolijanović et al. 2007; Dahmardeh et al. 2010). The weaker competitive pressure in intercrops, the greater advantage of intercropping. Due to this, Vandermeer (1989) introduced a new term in ecology of intercropping: competitive production principle. This principle points out to the optimal participation of species into intercrops.
The land equivalent ratio (LER) has been the best as a numerical parameter related to the interactions of species in intercrops. The effective LER, the most often applied in replacement series was used in studies of maize-pumpkin intercrops in the experimental field of the MRI, Zemun Polje (Riley 1984). Based on the LER index values presented in Table 7 and Figure 2, it can be concluded that maize-pumpkin intercrop did not expressed effectiveness over sole crops. Namely, the values of the LER index were below one in both years and farming systems.

Table 7. Land equivalent ratio in maize-pumpkin intercrop in different farming systems

\begin{tabular}{|c|c|c|c|c|c|c|c|}
\hline \multirow[t]{2}{*}{ Year } & \multirow[t]{2}{*}{$\begin{array}{l}\text { Intercropping } \\
\text { variants }\end{array}$} & \multicolumn{2}{|c|}{$\begin{array}{c}\mathbf{L}_{\mathrm{m}} \text { (relative yield of } \\
\text { maize) }\end{array}$} & \multicolumn{2}{|c|}{$\begin{array}{l}\text { Lp (relative yield of } \\
\text { pumpkins) }\end{array}$} & \multicolumn{2}{|c|}{ LER } \\
\hline & & $\mathrm{Cv}$ & Co & $\mathbf{C v}$ & Co & $\mathrm{Cv}$ & Co \\
\hline \multirow{3}{*}{2010} & $1 / 3 p: 2 / 3 \mathrm{~m}$ & 0.69 & 0.72 & 0.19 & 0.18 & 0.88 & 0.90 \\
\hline & $1 / 2: 1 / 2$ & 0.56 & 0.59 & 0.27 & 0.28 & 0.83 & 0.87 \\
\hline & 2/3p:1/3 m & 0.39 & 0.38 & 0.51 & 0.45 & 0.90 & 0.83 \\
\hline \multirow{6}{*}{2011} & Average & 0.55 & 0.56 & 0.32 & 0.30 & 0.87 & 0.86 \\
\hline & $1 / 3 p: 2 / 3 m$ & 0.68 & 0.76 & 0.15 & 0.17 & 0.83 & 0.93 \\
\hline & $1 / 2: 1 / 2$ & 0.53 & 0.63 & 0.16 & 0.30 & 0.69 & 0.93 \\
\hline & $2 / 3 \mathrm{p}: 1 / 3 \mathrm{~m}$ & 0.38 & 0.38 & 0.50 & 0.42 & 0.88 & 0.80 \\
\hline & Average & 0.53 & 0.59 & 0.27 & 0.30 & 0.80 & 0.89 \\
\hline & SE (D.F. $=24)$ & 0.039 & 0.047 & 0.048 & 0.034 & 0.022 & 0.015 \\
\hline
\end{tabular}

$\mathrm{Cv}$-conventional farming system; Co-conservation farming system; SE-standard error

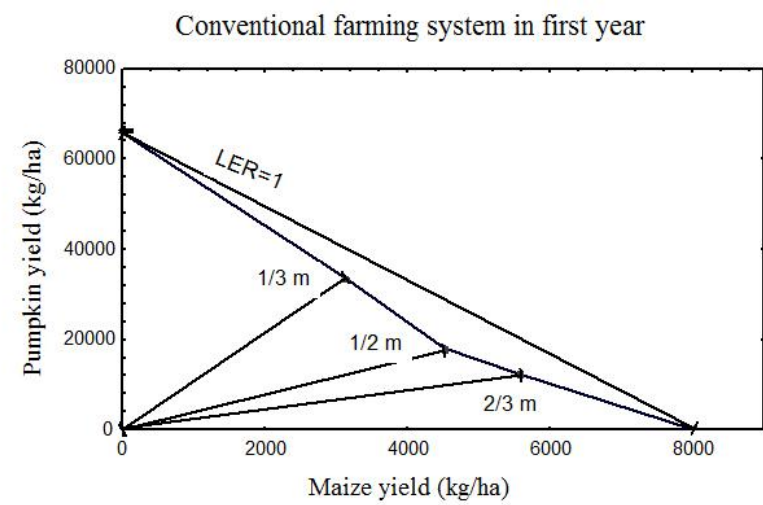

Conservation farming system in first year

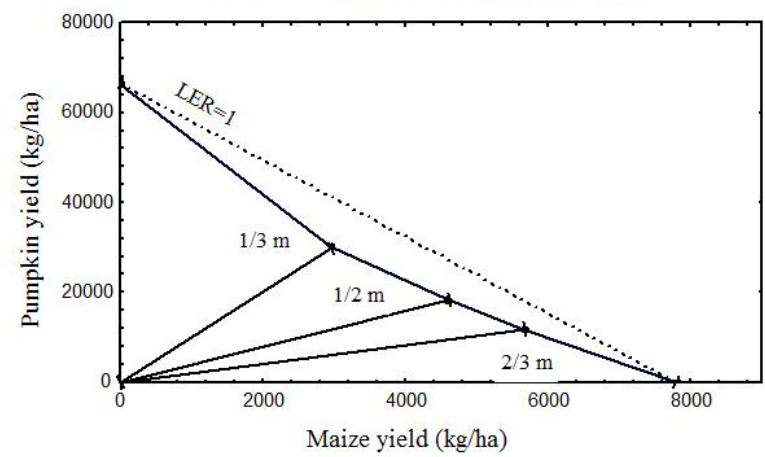

Conventional farming system in second year

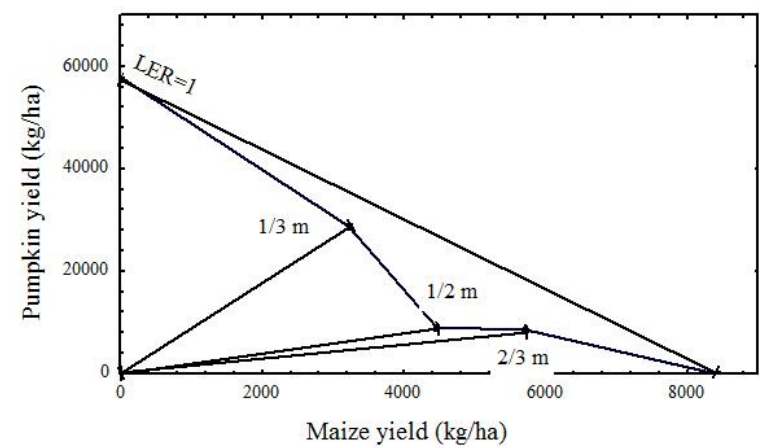

Conservation farming system in second year

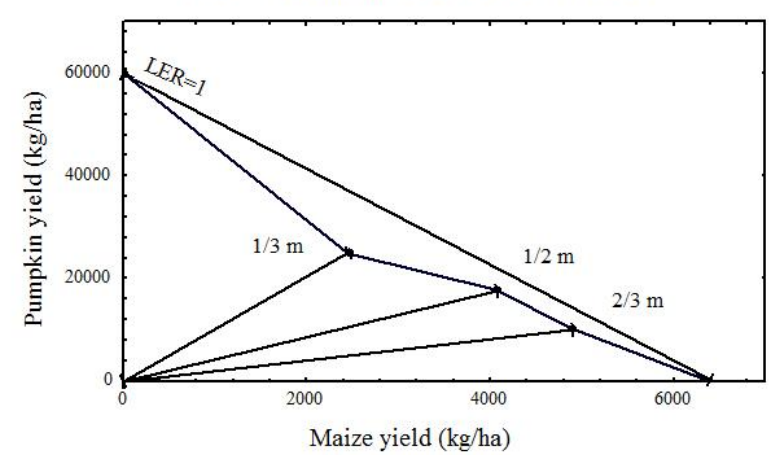

Figure 2. Bivariate diagrams of the maize-pumpkin intercropping system (the dashed line joining the monoculture yield of the two components represents conditions where $\mathrm{LER}=1$; the lines radiating from the origin indicates various proportions of component crops). 
The lowest values of the LER index were found in the conventional farming system in 2011, when the yield reduction in comparison to yields of sole crops amounted to $47 \%$ (maize) and $73 \%$ (pumpkins). Although intercropping does not always provide yield advantages over sole cropping, LER> 1 have been reported for many different intercropping systems (Oljača et al. 2000; Ullah et al. 2007; Marer et al. 2007; Dhima et al. 2007; Hugar and Palled 2008; Biabani et al. 2008). It has already been known that maize crop have been more competitive than pumpkin crop. Such competitive ability of maize was especially effective in $1 / 3: 2 / 3$ mixtures in both farming systems and seasons. This variant as well as the $1 / 2: 1 / 2$ variant can be recommended for farming practices, particularly when maize crop is grown. On the other hand, the $2 / 3: 1 / 3$ variant from the aspect of yields cannot be recommended. Efficiency increasing of maize-pumpkin intercrops can be achieved by the increase of the number of plants of both crops per area unit. These results indicate a close relationship between yield and plant density. So, Budakli Carpici et al. 2010, cited that dry matter yield was influenced by plant densities. Dry matter yield increased and reached maximum at 180000 plants ha- 1 and then declined as plant density increased further.

Advantage of the conventional farming system in maize-pumpkin intercrops is obvious. The only exception was a higher yield of maize obtained in conservation farming system in second season. When more effective growing practices are applied (such as conservation farming system) under unfavorable agroecological conditions, deficiency of certain factors will favor the utilization of others. It is always necessary to determine the types of interactions in intercrops in order to find out the best pattern arrangement of maize and pumpkins in which the competition is the lowest, while yield components (quantity and quality) are the highest.

\section{ACKNOWLEDGEMENTS}

This study was supported by the Ministry of Education, Science and Technological Development of the Republic of Serbia through the Project TR-31037.

\section{LITERATURE CITED}

Biabani, A., M. Hashemi and S.J. Herbert. 2008. Agronomic performance of two intercropped soybean cultivars. International Journal of Plant Production, 2: 215-222.

Biabani, A. 2009. Agronomic performance of intercropped Wheat cultivars. Asian Journal Plant Sci., 8: 78-81.

Birkás, M., A. Dexter, T. Kalmár and L. Bottlik. 2006. Soil quality-soil condition-production stability. Cereal. Research Communication, 34: 135-138.

Budakli Carpici, E., N. Çelik and G. Bayram. 2010. Yield and quality of forage maize as influenced by plant density and nitrogen rate. Turkish Journal of Field Crops, 15: 128-132.

Conteras Magana, E.S. and F. del Castillo. 1991. Preliminary trial of the performance of squashes, snap bean, and cucumbers with mulching and row covers. Rev. Chap., 5: 73-74.

Dahmardeh, M., A. Ghanbari, B.A. Syahsar and M. Ramrodi. 2010. The role of intercropping maize (Zea mays L.) and cowpea (Vigna unquiculata L.) on yield and soil chemical properties. African Journal of Agricultural Research, 5: 631636.

De Wit, C.T. 1960. On competition. Verslag Landbouw-Kundige Onderzoek, 66: 1-28.

Dhima, K.V., A.S. Lithourgidis, I.B. Vasilakoglou and C.A. Dordas. 2007. Competition indices of common vetch and cereal intercrops in two seeding ratio. Field Crops Research, 100: $249-256$

Dolijanović, Ž., S. Oljača, D. Kovačević and M. Simić. 2007. Effects of different maize hybrids on above-ground biomass in intercrops with soybean. Maydica, 52: 265-271.

Dolijanović, Ž., S. Oljača, D. Kovačević, M. Simić, N. Momirović and Ž. Jovanović. 2013. Dependence of the productivity of maize and soybean intercropping systems on hybrid type and plant arrangement pattern. Genetics, Belgrade, 45: 135-144.

Francis, C.A. 1986. Introduction: Distribution and importance of multiple cropping. In: Multiple Cropping System, (Ed. CA Francis), Macmillan Publishing Company, New York, USA, pp. 1-20.

Galloway, B.A. and L.A. Weston. 1996. Influence of cover crop and herbicide treatment on weed control and yield in no-till sweet corn and pumpkin. Weed Technology, 10: 341-346.

Gliessman, S.R. 1986. Plant interaction in multiple cropping systems. In: Multiple Cropping System, (Ed. CA Francis), Macmillan Publishing Company, New York, USA, pp. 8296.

Hugar, H.Y. and Y.B. Palled. 2008. Studies on maize-vegetable intercropping systems. Karnataka Journal of Agricultural Sci., 21: 159-161.

Ilker, E., F. Aykut Tonk, Ö. Çaylak, M. Tosun and I. Özmen. 2009. Assessment of genotype $\mathrm{x}$ environment interactions for grain yield in maize hybrids using ammi and gge biplot analyses. Turkish Journal of Field Crops, 14: 123-135.

Kuscu, H., A. Karasu, M. Oz, A.O. Demir, and I. Turgut. 2013. Effect of irrigation amounts applied with drip irrigation on maize evapotranspiration, yield, water use efficiency, and net return in a sub-humid climate. Turkish Journal of Field Crops, 18: 13-19.

Liebman, M. and P.C. Staver. 2001. Crop diversification for weed management. In: Ecological Management of Agricultural Weeds (Eds. M Liebman, CL Mohler, PC Staver) Cambridge University Press, Cambridge, UK, pp. 336-351.

Marer, S.B., B.S. Lingaraju and G.B. Shashidhara. 2007. Productivity and economics of maize and pigeonpea intercropping under rainfed condition in northern transitional zone of karnataka. Karnataka Journal of Agricultural Sci., 20: $1-3$.

Mead, R. 1986. Statistical methods for multiple cropping. In: Multiple Cropping System, (Ed. CA Francis), Macmillan Publishing Company, New York, USA, pp. 317-351.

Mitrović, B., D. Stanisavljević, S, Treskić, M. Stojaković, M. Ivanović, G. Bekavac and M. Rajković. 2012. Evaluation of experimental maize hybrids tested in multi-location trials using AMMI and GGE biplot analyses. Turkish Journal of Field Crops, 17: 35-40.

Mudita, I.I., C. Chiduza, S.J. Richardson-Kageler and F.S. Murungu. 2008. Performance of maize (Zea mays L.) and soya bean [Glycine $\max (\mathrm{L}$.) Merrill] cultivars of varying growth habit in intercrop in sub-humid environments of Zimbabwe. European Journal of Agronomy, 7: 229-236.

Oljača, S. 1998. Productivity of intercropped maize and bean on the irrigated and non irrigated conditions, $\mathrm{PhD}$ thesis. University of Belgrade, Faculty of Agriculture, 138. p. (in Serbian) 
Oljača, S., R. Cvetković, D. Kovačević, G. Vasić and N. Momirović. 2000. Effect of plant arrangement pattern and irrigation on efficiency of maize (Zea mays) and bean (Phaseolus vulgaris) intercropping system. Journal of Agricultural Sci. Cambridge, 135: 261-270.

Pearce, S.C. and B. Gilliver. 1978. The statistical analysis of data from intercropping experiments. Journal of Agricultural Sci. Cambridge, 91: 625-632.

Powers, L.E., R. McSorley, D.A. Dunn and A. Montes. 1993. The agroecology of cucurbit-based intercropping system in the Yeguare Valley of Honduras. Agriculture Ecosystem and Environment, 48: 139-147.

Riley, J. 1984. A general form of the "Land Equivalent Ratio", Experimental Agriculture, 20: 19-29.

Silwana, T. and E.O. Lucas. 2002. The effect of planting combinations and weeding on the growth and yield of component crops of maize/bean and maize/pumpkin intercrops. Journal of Agricultural Sci. Cambridge, 138: 193-200.

Snaydon, R.W. and E.H. Satorre. 1989. Bivariate diagrams for plant competition data: modification and interpretation. Journal of Applied Ecology, 26: 1043-1057.
Ullah, A., M.A. Bhatti, Z.A. Gurmani and M. Imran. 2007. Studies on planting patterns of maize (Zea mays L.) facilitating legumes intercropping. Journal of Agricultural Research, 45: 113-118.

Vandermeer, J.H. 1989. The Ecology of Intercropping. Cambridge University Press, Cambridge. $231 \mathrm{p}$.

Videnović, Ž., Ž. Jovanović, Z. Dumanović, M. Simić, J. Srdić, V. Dragičević and I. Spasojević. 2013. Effect of long term crop rotation and fertiliser application on maize productivity. Turkish Journal of Field Crops, 18: 233-237.

Willey, R.W. 1979a. Intercropping-Its importance and research needs. II. Agronomy and research approaches. Field Crop Abstract, 32: 73-85.

Willey, R.W. 1979b. Intercropping-Its importance and research needs. I. Competition and yield advantages. Field Crop Abstract, 32: 1-10.

Yang, C.H., Q. Chai and G.B. Huang. 2010. Root distribution and yield responses of wheat/maize intercropping to alternate irrigation in the arid areas of northwest China. Plant, Soil and Environmental, 56: 253-262. 